\title{
Shading And Slow Release Fertilizer Effects On The Growth Characteristics Of Assai Seedlings (Euterpe oleracea)
}

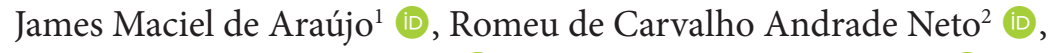 \\ João Ricardo de Oliveira ${ }^{1}$ (D), Aureny Maria Pereira Lunz ${ }^{2}$ (D), \\ Ueliton Oliveira de Almeida ${ }^{1}$
}

${ }^{1}$ Programa de Pós-Graduação em Produção Vegetal, Universidade Federal do Acre - UFAC, Rio Branco/AC, Brasil
${ }^{2}$ Empresa Brasileira de Pesquisa Agropecuária - EMBRAPA, Rio Branco/AC, Brasil

\begin{abstract}
The objective of this work was to evaluate the initial growth of assai seedlings (Euterpe oleraceae) in response to shading and slow release fertilizer. The experiment was conducted at Embrapa Acre in a randomized block design using a $4 \times 5$ factorial scheme with three replicates and 10 plants per plot. The treatments consisted of four shade environments $(20 \%, 30 \%, 50 \%$ and $75 \%)$ and five levels of slow release fertilizer $\left(0.0,2.5,5.0,7.5\right.$ and $\left.10.0 \mathrm{~kg} \mathrm{~m}^{-3}\right)$. The following characteristics were evaluated: plant height, number of leaves, stem diameter, leaf dry mass, stem dry mass, root dry mass, total dry mass, and seedlings quality index. The growth of assai seedlings was influenced by shade environment conditions and slow release fertilizer. Shade environment with $30 \%$ or $50 \%$ and a dose of $8 \mathrm{~kg} \mathrm{~m}^{-3}$ resulted in better quality seedlings.
\end{abstract}

Keywords: Western Amazon, mineral nutrition, palm. 


\section{INTRODUCTION}

The assai (Euterpe oleracea Mart.) is a plant of the Arecaceae family that occurs throughout the estuary of the Amazon River, mainly in the States of Pará, Amazonas, Maranhão and Amapá. According to Menezes et al. (2008), it is the most productive palm of the Amazon region being the fruit its main product.

Assai pulp is a source of mineral salts, mainly calcium and potassium, anthocyanins and fatty acids, and is considered an energetic food. Its functional value has been widely promoted, leading to an increase in demand for the fruit. As a consequence there is an increase in exploitation of areas containing native assai palm grove. There are also crop implantations on solid ground, according to Yokomizo et al. (2016), because extraction will not be able to meet growing demand.

A quality seedling has better growth conditions and competes for water, light and nutrients, and thus represents one of the most important inputs in the productive process because it will reflect on the productivity and longevity of field planting. However, for this to occur it is necessary that it is produced under conditions that enable better growth, nutrient absorption and development.

The environmental factors that most influence seedling production are luminosity and substrate (Dantas et al., 2009). The first, which can be artificially modified, can positively affect the growth rate and plant quality, with different effects depending on the ecological class of the species. The second is directly related to the nutritional status of the seedlings, since it is the basis for containing and supplying the elements necessary for the plant's initial growth.

The substrate generally does not have enough nutrients to support the proper growth of the plant, which makes it necessary to fertilize it through granulated fertilizer or to promote leaf fertilization directly to the seedlings. This process takes time and labor and leads to increased production costs. Due to its slow release, it reduces leaching losses and keeps the plant nourished, therefore slow release fertilizer is an alternative and can be increased in the productive process of assai seedlings.

In the literature, the cultivation environment and the nutritional question for producing assai seedlings has already been addressed. Conforto \& Contin (2009) verified that the development of assai palms in the nursery phase was considered satisfactory under conditions of $50 \%$ of the incident radiation, a result corroborated by Zancheta et al. (2013) and Dapont et al. (2016). Mendonça et al. (2006) concluded that the use of the substrate formed by plantmax + coffee bean peels + sawdust + sand and soil in the proportion of 1:1:1:1:2 $\mathrm{v} / \mathrm{v}$ associated with a slow release fertilizer dose of $4 \mathrm{~kg} \mathrm{~m}^{-3}$ is a good alternative for producing an assai palm seedling grove.

Nevertheless, a study involving the two mentioned factors was not carried out. Therefore the objective of this work was to evaluate the initial growth of assai seedlings under different shade environment conditions and slow release fertilizer doses.

\section{MATERIAL AND METHODS}

The experiment was installed and conducted between November 2015 and September 2016 in the experimental field of Embrapa Acre, located in the municipality of Rio Branco, Acre state, with coordinates $10^{\circ} 1^{\prime} 30^{\prime \prime} S$ and $67^{\circ} 42^{\prime} 18^{\prime \prime} \mathrm{W}$, with an altitude of approximately $160 \mathrm{~m}$. The climate of the region is hot and humid and classified as Awi according to the Köppen classification, with an annual average temperature of $24.5^{\circ} \mathrm{C}$, relative humidity of $84 \%$ and rainfall between 1,700 and $2,400 \mathrm{~mm}$ per year. The data for the shade environments during the evaluation period of the experiment were obtained through Datalogger AK 174 (Table 1).

Were used polyethylene bags with volumetric capacity of 3 liters containing substrate composed of the superficial red

Table 1. Maximum, minimum and average temperature, as well as relative air humidity recorded in the environments (shadehouses) in the total period of conducting the experiment.

\begin{tabular}{ccccc} 
Shade levels & \multicolumn{3}{c}{ Temperature $\left({ }^{\circ} \mathbf{C}\right)$} & $\begin{array}{c}\text { Relative air } \\
\text { humidity }\end{array}$ \\
\cline { 2 - 5 } $20 \%$ & Maximum & Minimum & Mean & $82.4 \%$ \\
$30 \%$ & 32.2 & 23.7 & 27.9 & $88.3 \%$ \\
$50 \%$ & 30.7 & 23.2 & 27.0 & $88.9 \%$ \\
$75 \%$ & 29.3 & 23.2 & 26.8 & $91.1 \%$ \\
\hline
\end{tabular}


argisol soil layer with the following chemical characteristics: $\mathrm{pH}\left(\mathrm{H}_{2} \mathrm{O}\right)=4.9 ; \mathrm{Ca}=2.92 \mathrm{cmol}_{\mathrm{c}} \mathrm{dm}^{-3} ; \mathrm{Mg}=0.82 \mathrm{cmol}_{\mathrm{c}} \mathrm{dm}^{-3} ;$ $\mathrm{K}=0.07 \mathrm{cmol}_{\mathrm{c}} \mathrm{dm}^{-3} ; \mathrm{Al}+\mathrm{H}=3.69 \mathrm{cmol}_{\mathrm{c}} \mathrm{dm}^{-3}$; $\mathrm{P}=38.22 \mathrm{mg} \mathrm{L}^{-1}$; CEC $(\mathrm{pH} 7)=7.50 \mathrm{cmol}_{\mathrm{c}} \mathrm{dm}^{-3}$; $\mathrm{BS}=50.74 \% ; \mathrm{OM}=11.89 \mathrm{~g} \mathrm{~kg}^{-1}$. An assai palm seed (Euterpe oleraceae Mart.), Cv. BRS-Pará, was placed in each of the containers (plastic bags) placed directly on the floor of the shadehouse and spaced $20 \mathrm{~cm}$ apart, pre-twinned and in the toothpick stage, obtained by sowing containing tanned sawdust.

The experimental design was a randomized block with three replicates and 10 plants per plot in a $4 \times 5$ factorial scheme with four shade environments (20\%, 30\%, 50\% and $75 \%)$ and five slow release fertilizer doses $\left(0.0,2.5,5.0,7.5\right.$ and $\left.10.0 \mathrm{~kg} \mathrm{~m}^{-3}\right)$ mixed with the substrate. Each shade environment had dimensions of $3.5 \mathrm{~m} \times 5.50 \mathrm{~m} \times 2.35 \mathrm{~m}$ (width, length and height, respectively) and the base (floor) was constituted of gravel no. 1. The slow release fertilizer used was the Osmocote 15-09-12, with a release time occurring over eight months and the following nutritional guarantees: $15 \% \mathrm{~N} ; 9 \% \mathrm{P}_{2} \mathrm{O}_{5} ; 12 \% \mathrm{~K}_{2} \mathrm{O} ; 1.3 \% \mathrm{Mg} ; 6 \% \mathrm{~S} ; 0.05 \% \mathrm{Cu}$; $0.46 \% \mathrm{Fe} ; 0.06 \% \mathrm{Mn} ; 0.02 \% \mathrm{Mo}$.

The seedlings were irrigated by a micro sprinkler system aiming to maintain the substrate at $75 \%$ of field capacity. Hand weeding was performed monthly to control weeds. No pest or disease control was carried out because it was unnecessary.

The characteristics evaluated at 240 days after transplanting the seedlings were: plant height $(\mathrm{cm})$, measured between the stem and the emission point of the leaflet of the highest leaf; stem diameter ( $\mathrm{mm}$ ), measured at $2 \mathrm{~cm}$ from the soil surface using a digital caliper; and number of active leaves, being those with chlorophyll area above $50 \%$.

Afterwards, the polyethylene bags and the clod adhered to the roots were removed so the plants could be washed in clean running water to remove excess substrate. Then, the parts of the seedlings (shoots (stem and leaves) and root system) were separated with pruning shears, packed in paper bags with a capacity of $0.5 \mathrm{~kg}$ and taken to the Embrapa Acre bromatology laboratory to be dried in an oven at $65^{\circ} \mathrm{C}$ until reaching a constant mass to determine the dry mass of: stem $(\mathrm{g})$, leaves $(\mathrm{g})$, roots $(\mathrm{g})$ and total dry mass $(\mathrm{g})$, using a precision scale.

Seed quality index (DQI) was determined as a function of total dry mass (TDM), plant height (H), stem diameter (SD), shoot dry mass (SDM), and root dry mass (RDM), according to the following Formula 1 (Dickson et al., 1960):

$$
D Q I=\frac{T D M(g)}{(H(\mathrm{~cm}) / S D(\mathrm{~mm})+(S D M(\mathrm{~g}) / R D M(\mathrm{~g}))}
$$

Data were submitted to analysis of variance (ANOVA). The Tukey test was applied for the qualitative factor and regression analysis was performed for the quantitative factor, both at $5 \%$ probability.

\section{RESULTS AND DISCUSSION}

There was interaction between shade environments and slow release fertilizer doses for the variables plant height and stem diameter. The number of leaves was only influenced by the isolated effect of the shade environment (Table 2).

Table 2. Analysis of variance for plant height (PH), stem diameter (SD), number of leaves (NL), leaf dry mass (LDM), stem dry mass (SDM), root dry mass (RDM), total dry mass (TDM) and Dickson quality index (DQI) of assai seedlings (Euterpe oleracea) evaluated at 240 days after transplanting in response to shading (ES) and slow release fertilizer (F). Rio Branco, Acre, 2017.

\begin{tabular}{|c|c|c|c|c|c|c|c|c|}
\hline \multicolumn{2}{|l|}{ Source } & ES (E) & Doses (D) & $E \times D$ & Block & Residual & Mean & CV (\%) \\
\hline \multicolumn{2}{|l|}{ d.f. } & 3 & 4 & 12 & 2 & 571 & - & - \\
\hline \multirow{8}{*}{$\begin{array}{c}\text { Mean Square } \\
(\mathrm{MS})\end{array}$} & PH & $2150.12^{*}$ & $3195.05^{*}$ & $209.83^{*}$ & 83.43 & 45.71 & 36.26 & 18.65 \\
\hline & SD & $186.81^{\star}$ & $467.56^{\star}$ & $21.98^{\star}$ & 9.24 & 7.29 & 16.66 & 16.21 \\
\hline & $\mathrm{NL}$ & $10.98^{*}$ & $3.14^{\mathrm{ns}}$ & $5.22^{\text {ns }}$ & 2.15 & 3.02 & 4.95 & 35.1 \\
\hline & LDM & $44.24^{*}$ & $304.93^{*}$ & $10.64^{*}$ & 3.98 & 2.18 & 5.32 & 27.77 \\
\hline & SDM & $45.98^{*}$ & $124.22^{\star}$ & $4.01^{\star}$ & 0.95 & 0.86 & 3.11 & 29.78 \\
\hline & RDM & $357.54^{*}$ & $261.05^{\star}$ & $63.26^{*}$ & 1.72 & 1.9 & 3.78 & 26.5 \\
\hline & TDM & $558.93^{*}$ & $1316.45^{\star}$ & $40.35^{\star}$ & 15.38 & 11.81 & 12.22 & 28.12 \\
\hline & DQI & $0.19^{*}$ & $0.27^{\star}$ & $0.01^{\star}$ & 3.04 & 0.01 & 0.53 & 2.81 \\
\hline
\end{tabular}

${ }^{*}$ Significance at $5 \%$. ${ }^{\mathrm{ns}}$ not significant according to the F-test. $\mathrm{CV}=$ coefficient of variation. 
Plant height was adjusted to the quadratic regression model for all environments as a function of slow release fertilizer doses (Figure 1). The environments with $50 \%$ and $75 \%$ shade promoted the highest heights, being $44.68 \mathrm{~cm}$ with the dose of $6.46 \mathrm{~kg} \mathrm{~m}^{-3}$ and $43.89 \mathrm{~cm}$ with the dose of $7.25 \mathrm{~kg} \mathrm{~m}^{-3}$, respectively.

According to Lopes et al. (2013), the ability to grow in height when shaded is an important mechanism in species adaptation with strategies of being competitors or even pioneers. It is a way to overcome the light deficiency, since these species are not able to tolerate low light intensities by adjusting their metabolic rates.

Conforto \& Contin (2009) verified that the shoot height of assai seedlings groves was not affected by the light treatment (50\% and 16\%). Differently, in this study $20 \%$ of shade resulted in lower plant height.

The literature finds that slow release fertilizers cause an increase in the seedling height of forest species (Dutra et al., 2016; Rossa et al., 2013; Zamunér et al.,
2012; Lang et al., 2011; Rossa et al., 2011; Brondani et al., 2008).

Plant height is one of the main biometric characteristics used in evaluating seedling growth. As it is easily measured and not destructive, it has been routinely determined in experiments related to plant species propagation. However, it should not be considered in isolation, since a taller seedling does not necessarily mean better quality. In some cases, light deficiency or excess nitrogen cause the plants to etiolation, which is mainly characterized by higher plant height and reduced stem diameter and dry masses.

The stem diameter was adjusted to the quadratic regression model for the shade environments as a function of the slow release fertilizer doses, except for the $30 \%$ shade environment whose adjustment was linear (Figure 2). The highest values of $19.18 \mathrm{~mm}$, $19.53 \mathrm{~mm}$ and $19.80 \mathrm{~mm}$ were obtained with doses of $7.13 \mathrm{~kg} \mathrm{~m}^{-3}, 6.87 \mathrm{~kg} \mathrm{~m}^{-3}$ and $10 \mathrm{~kg} \mathrm{~m}^{-3}$ in $50 \%, 20 \%$ and $30 \%$ shade environments, respectively.

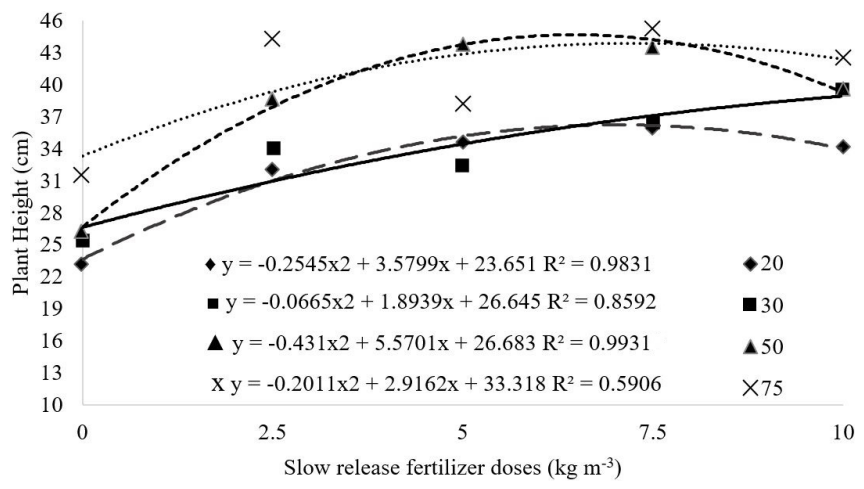

Figure 1. Plant height ( $\mathrm{PH}$ ) of assai seedlings (Euterpe oleracea) evaluated at 240 days after transplanting in response to shading and slow release fertilizer. Rio Branco, Acre, 2017.

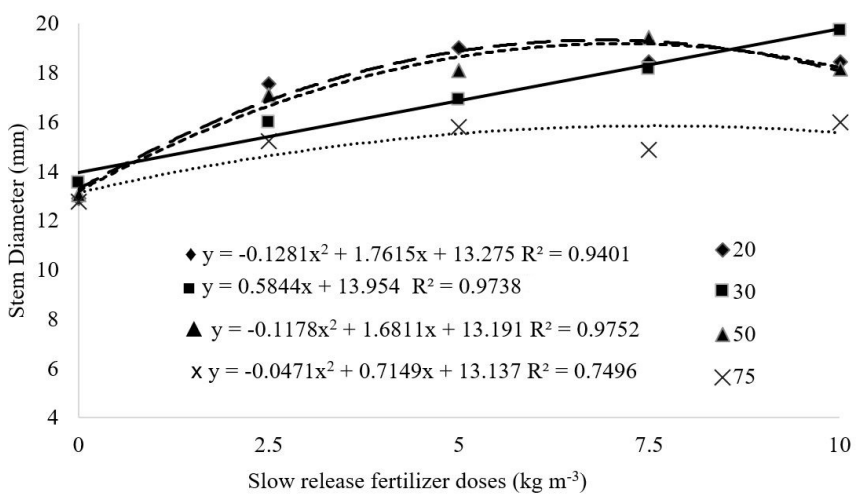

Figure 2. Stem diameter (SD) of assai seedlings (Euterpe oleracea) evaluated at 240 days after transplanting in response to shading and slow release fertilizer. Rio Branco, Acre, 2017. 
Although Zancheta et al. (2013) showed that assai seedlings require shade levels close to $50 \%$, the values of the stem diameters in the $20 \%$ and $30 \%$ environments were very close to the level related to $50 \%$ shading, probably due to the effect promoted by release fertilizer on plant growth.

The shade environment related to $75 \%$ led to the smallest diameter of the plants, independent of the slow release fertilizer doses applied. This may have occurred due to the reduced metabolic rates and less photoassimilate availability, which is essential to plant growth since there is a decrease in photosynthesis in shaded environments (Silva et al., 2007; Favreto et al., 2010). Dapont et al. (2016) observed that the stem diameter in assai seedling groves decreased as a function of increased shading. Gatti et al. (2011) verified that $10 \%$ of maximum irradiance input led Euterpe edulis plants to reach the smallest stem diameter.

Dutra et al. (2016), Lang et al. (2011) and Martins et al. (2011) verified an increase in stem diameter due to the application of slow release fertilizer in: Peltophorum dubium, Tabebuia avellanedae and Anadenanthera colubrina, Chaenomeles sinensis, respectively.

Shade environments, slow release fertilizer doses, as well as the interaction between these two factors had a significant influence $(\mathrm{p}<0.05)$ on the dry mass variables of leaves, shoot, root, total dry mass and quality index of seedlings (Table 2).

Environments with 20\%,30\% and 50\% shade resulted in seedlings with a greater number of leaves (Table 3).

According to César et al. (2014), a greater number of leaves in intermediate shades close to $47 \%$ observed in the Pterogyne nitens species can be attributed to optimizing photosynthesis and microclimatic conditions, with a reflection on greater carbohydrate accumulation and accelerated leaf emission. Gatti et al. (2011) verified that the annual production of Euterpe edulis leaves increased with increasing irradiance, being higher in the treatments corresponding to $65 \%$, lower in the treatment with $10 \%$ light, and intermediate in treatments with $30 \%$ and $40 \%$ of the maximum light. Intermediate shading of around $30 \%$ resulted in a higher number of leaves in coffee seedlings (César et al., 2010). For the Schizolobium parahyba species, the number of leaves was not influenced by shading levels of 30\%,50\% and 70\% (Caron et al., 2010).

Leaf dry mass adjusted to the quadratic regression model for shade environments as a function of slow release fertilizer doses (Figure 3). The highest dry mass of the leaves was in the environments of $30 \%$ and $50 \%$ with the doses of $9.24 \mathrm{~kg}$ of fertilizer per $\mathrm{m}^{3}$ of substrate and $7.00 \mathrm{~kg}$ of fertilizer per $\mathrm{m}^{3}$ of substrate, obtaining $6.88 \mathrm{~g}$ and $6.76 \mathrm{~g}$, respectively.

Table 3. Number of leaves (NL) of assai seedlings (Euterpe oleracea) evaluated at 240 days after transplanting in response to shading and slow release fertilizer. Rio Branco, Acre, 2017.

\begin{tabular}{|cc|}
\hline Shading (\%) & NL \\
\hline 20 & $5.10 \mathrm{a}$ \\
30 & $5.07 \mathrm{a}$ \\
50 & $5.09 \mathrm{a}$ \\
\hline 75 & $4.54 \mathrm{~b}$ \\
\hline $\mathrm{CV}(\%)$ & 36.5 \\
\hline
\end{tabular}

Means followed by the same letter do not differ by the Tukey test $(\mathrm{p}>0.05)$.

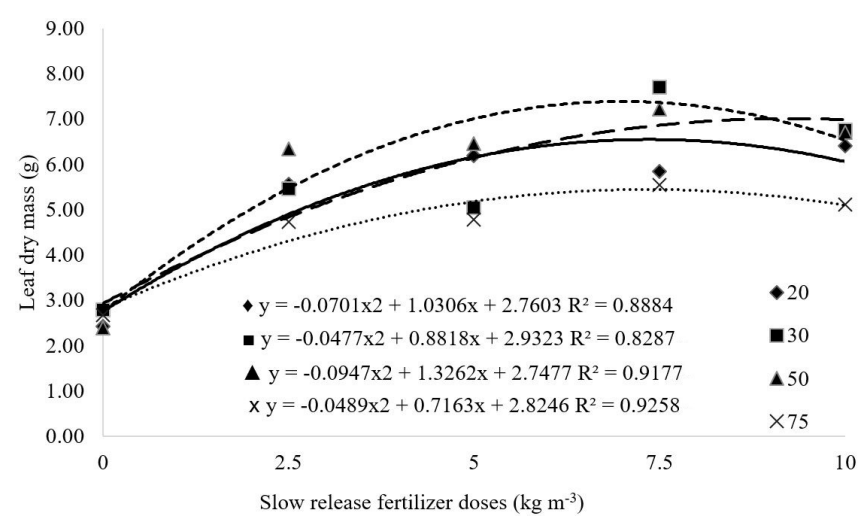

Figure 3. Leaf dry mass (LDM) of assai seedlings (Euterpe oleracea) evaluated at 240 days after transplanting in response to shading and slow release fertilizer. Rio Branco, Acre, 2017. 
The leaf dry mass values determined in this study are more than twice those detected by Conforto \& Contin (2009) for the same species at the same evaluation time and submitted to two levels of radiation attenuation (50\% and $16 \%$ ). This can be explained by the addition of the slow release fertilizer that led the plants to show higher growth, since fertilization is one of the main factors for plant growth.

In the work developed by Nakazono et al. (2001), Euterpe edulis seedlings in 20\%, 30\% and 50\% shade environments showed a greater increase in the leaf, root and shoot dry mass (stem and leaves).

The dry mass of coffee leaves was higher when a slow release fertilizer dose of up to $15.28 \mathrm{~kg} \mathrm{~m}^{-3}$ of plantmax substrate was applied (Marana et al., 2008). For the angico-branco species, Brondani et al. (2008) verified a quadratic increase of leaf dry mass as a function of slow release fertilizer doses.

The zero fertilizer dose resulted in lower values of the analyzed variables for all environments, including dry leaf mass, which leads to the conclusion that there is a need for supplementing nutrition for the satisfactory growth of assai seedlings.

For stem dry mass, there was an adjustment to the quadratic regression model for different environments due to the applied slow release fertilizer doses (Figure 4). The environments with $30 \%$ and $50 \%$ shade in the $7 \mathrm{~kg}$ fertilizer doses per $\mathrm{m}^{3}$ of substrate and $9.2 \mathrm{~kg}$ of fertilizer per $\mathrm{m}^{3}$ of substrate presented the highest values of dry mass with $4.41 \mathrm{~g}$ and $4.58 \mathrm{~g}$, respectively.

In an 8 month-old assai seedling grove, Conforto \& Contin (2009) recorded a mean of $3.42 \mathrm{~g}$ and $3.73 \mathrm{~g}$ for the stem in environments with $50 \%$ and $16 \%$ of shade, respectively. Dapont et al. (2016) found that the shoot dry mass of assai seedlings (Euterpe oleracea) occurred in an environment with $40 \%$ shade.

According to Larcher (2006), plants submitted to environments with higher light intensity levels present higher values for dry mass accumulation due to better liquid assimilation. However, this depends on the species and even on other conditions that may interfere with the production environment.

According to Viégas et al. (2009), the fertilization directly influences the increase and mass accumulation of the stem, where assai plants with nutritional deficits presented reductions in the dry mass of $70 \%$ when compared to fertilized plants.

When studying the effect of the slow release fertilizer associated to substrates in the production of assai seedlings in a nursery with $50 \%$ shade, Mendonça et al. (2006) obtained seedlings with a higher shoot dry mass until the maximum dose of $4 \mathrm{~kg} \mathrm{~m}^{-3}$.

There was adjustment to the quadratic regression model for root dry mass in the environments of $20 \%$, $30 \%$ and $50 \%$ of shade, respectively, resulting in $3.89 \mathrm{~g}$ with the dose of $8.52 \mathrm{~kg} \mathrm{~m}^{-3}, 4.86 \mathrm{~g}$ at the dose of $7.06 \mathrm{~kg} \mathrm{~m}^{-3}$ and $4.62 \mathrm{~g}^{2}$ the dose of $8.67 \mathrm{~kg} \mathrm{~m}^{-3}$ substrate (Figure 5). The environment related to $75 \%$ shade was not significant $(\mathrm{p}>0.05)$.

Thus, the root dry mass of the assai increased with increasing doses of slow release fertilizer; a fact observed in different species: rubber tree rootstock (Zamunér et al., 2012); banana tree (Martins et al., 2011; Nomura et al., 2009); peach palm (Martins et al.,

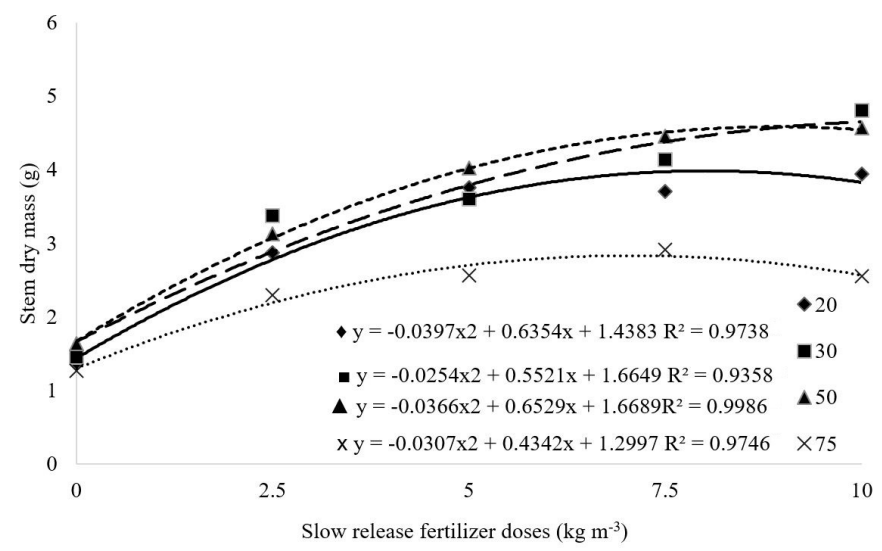

Figure 4. Stem dry mass (SDM) of assai seedlings (Euterpe oleracea) evaluated at 240 days after transplanting in response to shading and slow release fertilizer. Rio Branco, Acre, 2017. 
2007); and tamarind (Mendonça et al., 2008). However, according to Poorter \& Nagel (2000), fertilizer levels above what is necessary can compromise root dry biomass, especially when they reach toxic levels.

It can be noticed that seedlings produced in environments with medium to high luminosity present higher dry root mass content. In this direction, Carvalho et al. (2006) report that plants with greater light intensity have greater dry mass accumulation in the root, which allows greater absorption of water and nutrients. This strategy can guarantee the plant the ability to withstand higher photosynthesis and transpiration rates in more illuminated environments. According to Bonamigo et al. (2016), the greater the root system dry mass, the greater the survival and quality of the plant, because there will be greater facility for nourishment and greater area for water and nutrients absorption by the plants.

The total dry mass of the assai seedlings conformed to the quadratic regression model for the different shade environments and slow release fertilizer doses (Figure 6). The environments with shade levels of $30 \%$ and $50 \%$ at the doses of $9.47 \mathrm{~kg} \mathrm{~m}^{-3}$ and $7.8 \mathrm{~kg} \mathrm{~m}^{-3}$ of substrate presented the highest values of total dry mass, being $16.53 \mathrm{~g}$ and $16.57 \mathrm{~g}$, respectively.

Results observed by Dapont et al. (2016) confirm that assai seedlings (E. oleracea) present a higher total dry mass in shades of $20 \%$ to $50 \%$. In Euterpe edulis seedlings submitted to environments of $70 \%$ to $96 \%$ luminosity, a greater increase of dry mass was verified in the seedlings (Nakazono et al., 2001). Reis et al. (2016) verified higher total dry mass value

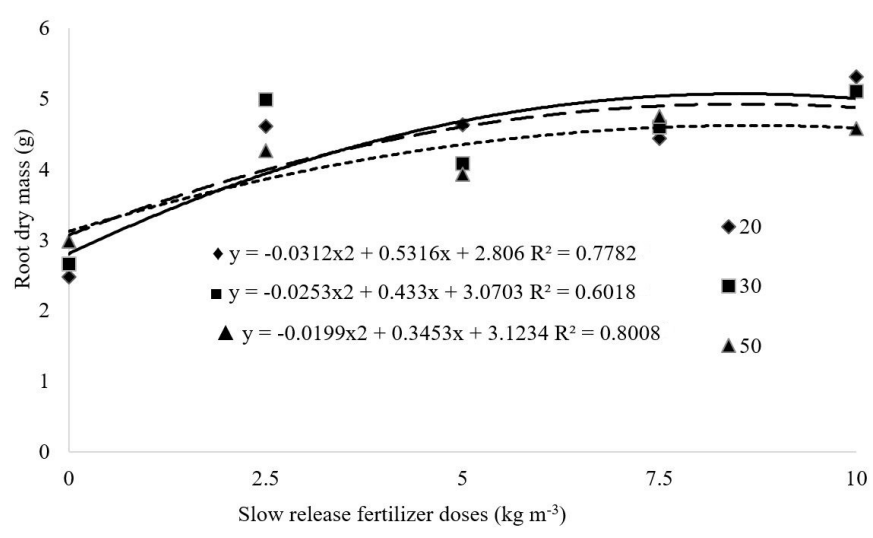

Figure 5. Root dry mass (RDM) of assai seedlings (Euterpe oleracea) evaluated at 240 days after transplanting in response to shading and slow release fertilizer. Rio Branco, Acre, 2017.

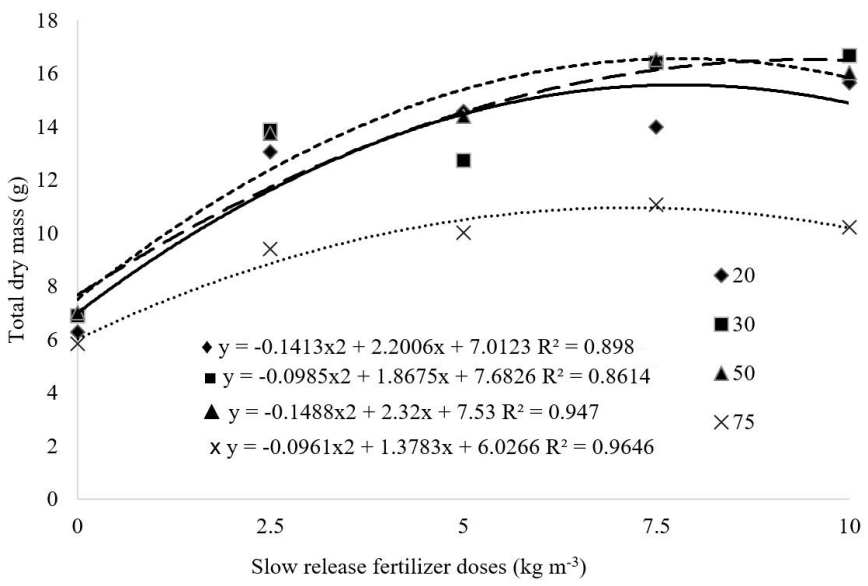

Figure 6. Total dry mass (TDM) of assai seedlings (Euterpe oleracea) evaluated at 240 days after transplanting in response to shading and slow release fertilizer. Rio Branco, Acre, 2017. 


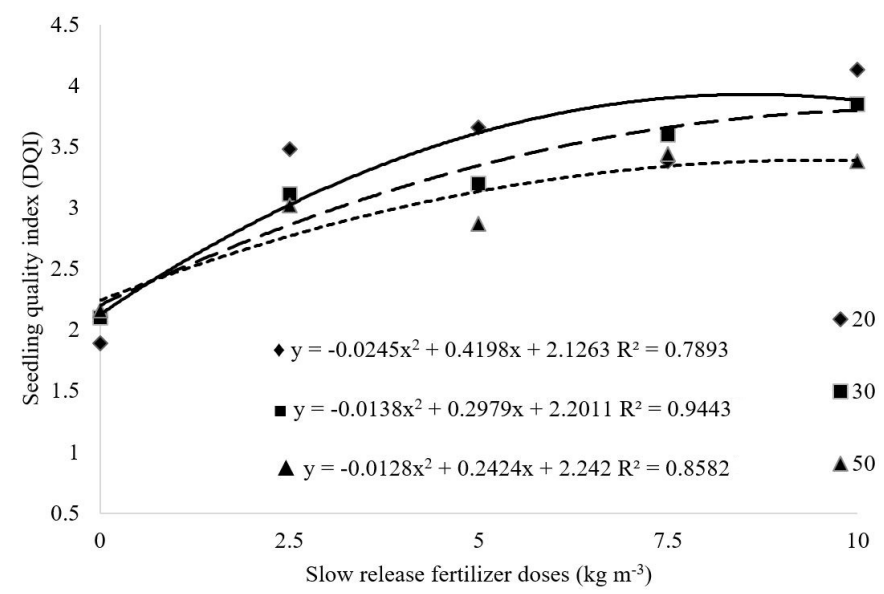

Figure 7. Dickson Quality Index (DQI) of assai seedlings (Euterpe oleracea) evaluated at 240 days after transplanting in response to shading and slow release fertilizer. Rio Branco, Acre, 2017.

in Copaifera langsdorffii seedlings in an environment with $54 \%$ shading.

Eucalyptus seedlings had their total dry mass increased as a function of slow release fertilizer doses and substrates (Silva et al., 2013), as well as papaya seedlings (Serrano et al., 2010). Moraes et al. (2003) verified that seedlings of five tree species had better quality, including higher total biomass when fertilized with controlled release fertilizer.

For the Dickson quality index, there was an adjustment to the quadratic regression model due to the shadow environment and slow release fertilizer (Figure 7). The environment related to $75 \%$ of shade had no significance, and the environment of $20 \%$ presented higher DQI value, being 3.92 in the dose of $8.56 \mathrm{~kg} \mathrm{~m}^{-3}$ of substrate.

Aguiar et al. (2011) obtained better results for quality index of Brazilwood seedlings (Caesalpinia echinata) in environments with $20 \%$ shade. Lopes et al. (2013) verified that $A$. germinans seedlings presented higher DQI values obtained in full sun and 30\% shading. In a $20 \%$ shade growing environment, Maranho \& Paiva (2012) observed higher DQI for rosewood seedlings (Physocalymma scaberimum).

Dutra et al. (2016) did not detect an effect of slow release fertilizers on the DQI variable in Cassia-fistula, L. seedlings. Rossa et al. (2014), Melo et al. (2015) and Rossa et al. (2015) detected positive effects of slow release fertilizer doses on Gallesia integrifolia, yellow passion fruit, red angico and red passion fruit seedlings, respectively.
Cruz et al. (2011) affirm that the DQI, as it expresses the quality of the seedlings, considers the robustness and balance of the biomass distribution in the seedling. According to Santelices et al. (2015), it depends on several production factors such as sowing time, pre-germination treatments and fertilization. In this work, in addition to the mentioned factors, it is evident that shading and its interaction with slow release fertilizer influence the quality index of seedlings.

There is still no recommended DQI value for producing assai seedlings. This value should be established and validated at the field level.

\section{CONCLUSIONS}

The growth of assai seedling groves is influenced by shade environment conditions and slow release fertilizer doses.

In the production of assai seedlings, the environment with $30 \%$ or $50 \%$ shade with $8 \mathrm{~kg}$ gradual release fertilizer dose per $\mathrm{m}^{3}$ of substrate provides higher quality seedlings.

\section{ACKNOWLEDGEMENTS}

À Embrapa Acre e à Universidade Federal do Acre pelo apoio técnico e financeiro para a realização da pesquisa. 


\section{SUBMISSION STATUS}

Received: 18 jan., 2018

Accepted: 17 jul., 2018

\section{CORRESPONDENCE TO}

\section{James Maciel de Araújo}

Programa de Pós-graduação em Produção Vegetal, Universidade Federal do Acre - UFAC, Rodovia BR 364, Km 04, Distrito Industrial, CEP 69920-900, Rio Branco,AC, Brasil e-mail: jamesagro3@gmail.com

\section{FINANCIAL SUPPORT}

Empresa Brasileira de Pesquisa Agropecuária (EMBRAPA SEG: 12.16.04.029.00.00).

\section{REFERENCES}

Aguiar FFA, Kanashiro S, Tavares AR, Nascimento TDR, Rocco FM. Crescimento de mudas de pau-brasil (Caesalpinia echinata Lam.), submetidas a cinco níveis de sombreamento. Revista Ceres 2011; 58(6): 729-734. http://dx.doi.org/10.1590/S0034-737X2011000600008.

Bonamigo T, Scalon SDPQ, Pereira ZV. Substratos e níveis de luminosidade no crescimento inicial de mudas de tocoyena formosa (cham. \& schltdl.) k. schum. (rubiaceae). Ciência Florestal 2016; 26(2): 501-511. http://dx.doi. org/10.5902/1980509822750.

Brondani GE, Silva AJC, Rego SS, Grisi FA, Nogueira AC, Wendling I et al. Fertilização de liberação controlada no crescimento inicial de angico-branco. Scientia Agraria 2008; 9(2): 167-176. http://dx.doi.org/10.5380/rsa.v9i2.10965.

Caron BO, Souza VQ, Cantarelli EB, Manfron PA, Behling A, Eloy E. Crescimento em viveiro de mudas de Schizolobium parahyba (Vell.) S. F. Blake. submetidas a níveis de sombreamento. Ciência Florestal 2010; 20(4): 683-689. http://dx.doi.org/10.5902/198050982427.

Carvalho NOS, Pelacani CR, Rodrigues MOS, Crepaldi IC, Crescimento inicial de plantas de licuri (syagrus coronata (mart.) becc.) em diferentes níveis de luminosidade. Revista Árvore 2006; 30(3): 351-357. http://dx.doi.org/10.1590/ S0100-67622006000300005.

César FRCF, Matsumoto SN, Viana AES, Bonfim JA. Crescimento inicial e qualidade de mudas de Pterogyne nitens Tull. conduzidas sob diferentes níveis de restrição luminosa artificial. Ciência Florestal 2014; 24(2): 357-366. http://dx.doi.org/10.5902/1980509814573.

César FRCF, Matsumoto SN, Viana AES, Santos MAF, Bonfim JA. Morfofisiologia foliar de cafeeiro sob diferentes níveis de restrição luminosa. Coffee Science 2010; 5(3): 262-271.

Conforto EC, Contin DR. Desenvolvimento do açaizeiro de terra firme, cultivar Pará, sob atenuação da radiação solar em fase de viveiro. Bragantia 2009; 68(4): 979-983. http://dx.doi.org/10.1590/S0006-87052009000400018.

Cruz CAF, Paiva HN, Cunha ACMCM, Neves JCL. Crescimento e qualidade de mudas de Fedegoso cultivadas em latossolo vermelho-amarelo em resposta a macronutrientes. Scientia Forestalis 2011; 39(89): 21-33.

Dantas BF, Lopes AP, Silva FFS, Lúcio AA, Batista PF, Pires MMML et al. Taxas de crescimento de mudas de catingueira submetidas a diferentes substratos e sombreamentos. Revista Árvore 2009; 33(3): 413-423. http://dx.doi.org/10.1590/S0100-67622009000300003.

Dapont EC, Silva JB, Alves CZ. Initial development of açaí plants under shade gradation. Revista Brasileira de Fruticultura 2016; 38(2): 1-9. http://dx.doi.org/10.1590/010029452016022.

Dickson A, Leaf AL, Hosner JF. Quality appraisal of white spruce and White pine seedling stock in nurseries. Forestry Chronicle 1960; 36(1): 10-13. http://dx.doi.org/10.5558/ tfc36010-1.

Dutra TR, Massad MD, Sarmento MFQ, Matos PS, Oliveira JC. Fertilizante de liberação lenta no crescimento e qualidade de mudas de canafístula (Peltophorum dubium). Floresta 2016; 46(4): 491-498. http://dx.doi.org/10.5380/ rf.v46i4.44570.

Favreto R, Mello RSP, Baptista LRM. Growth of Euterpe edulis Mart. (Arecaceae) under forest and agroforestry in southern Brazil. Agroforestry Systems 2010; 80(2): 303-313. http://dx.doi.org/10.1007/s10457-010-9321-z.

Gatti MG, Campanello PI, Goldstein G, Growth and leaf production in the tropical palm Euterpe edulis: Light conditions versus developmental constraints. Flora 2011; 206(8): 742-748. http://dx.doi.org/10.1016/j. flora.2011.04.004

Lang A, Malavasi UC, Decker V, Pérez PV, Aleixo MA, Malavasi MM. Aplicação de fertilizante de liberação lenta no estabelecimento de mudas de ipê-roxo e angico-branco em área de domínio. Floresta 2011; 41(2): 271-276. http:// dx.doi.org/10.5380/rf.v41i2.21874.

Larcher W. Ecofisiologia vegetal. São Carlos: RIMA Artes e Textos; 2006. $532 \mathrm{p}$.

Lopes EC, Araujo EC, Costa RS, Daher RF, Fernandes MEB. Crescimento de mudas de mangue sob diferentes níveis de sombreamento na península de Ajuruteua, Bragança, Pará. Acta Amazonica 2013; 43(3): 291-296. http://dx.doi.org/10.1590/S0044-59672013000300004.

Marana JP, Miglioranza É, Fonseca ÉP, Kainuma RH. Índices de qualidade e crescimento de mudas de café produzidas em tubetes. Ciência Rural 2008; 38(1): 39-45. http://dx.doi.org/10.1590/S0103-84782008000100007. 
Maranho ÁS, Paiva AV. Produção de mudas de physocalymma scaberrimum em substratos compostos por diferentes porcentagens de resíduo orgânico de açaí. Revista Floresta 2012; 42(2): 399-408. http://dx.doi.org/10.5380/ rf.v42i2.19220.

Martins AN, Poz LD, Suguino E, Dias NMS, Perdoná MJ. Aclimatação de mudas micropropagadas de bananeira "Nanicão Williams" em diferentes substratos e fontes de nutrientes. Agrária 2011; 6(1): 65-72. http://dx.doi. org/10.5039/agraria.v6ila912.

Martins S Fo, Ferreira A, Andrade BS, Rangel RM, Silva MF. Diferentes substratos afetando o desenvolvimento de palmeiras. Revista Ceres 2007; 54(3): 80-86.

Melo JCF Jr, Costa DDS, Gervásio ES, Lima AMN, Sediyama GC. Efeito de níveis de depleção de água no substrato e doses de fertilizante de liberação controlada na produção de mudas de maracujazeiro amarelo. Irriga 2015; 20(2): 204-219. http://dx.doi.org/10.15809/irriga.2015v20n2p204.

Mendonça V, Abreu NAA, Souza HA, Teixeira GA, Hafle OM, Ramos JD. Diferentes ambientes e osmocote ${ }^{\varpi}$ na produção de mudas de tamarindeiro (Tamarindus indica). Ciência e Agrotecnologia 2008; 32(2): 391-397. http:// dx.doi.org/10.1590/S1413-70542008000200007.

Mendonça V, Correa FLO, Carvalho JG, Ramos JD, Gontijo TCA, Carrijo EP. Substratos e doses de fertilizantes de liberação controlada na produção de mudas de açaí (Euterpe oleraceae Mart.). Revista de Ciências Agrárias 2006; 46(3): 275-285.

Menezes EMS, Torres AT, Sabaa Srur AU. Valor nutricional da polpa de açaí (Euterpe oleracea Mart) liofilizada. Acta Amazonica 2008; 38(2):311-316. http://dx.doi.org/10.1590/ S0044-59672008000200014.

Moraes SP No, Gonçalves JLM, Rodrigues CJ, Geres WLA, Ducatti F, Aguirre JH Jr, Produção de mudas de espécies arbóreas nativas com combinações de adubos de liberação controlada e prontamente solúveis. Revista Árvore 2003; 27(6): 779-789. http://dx.doi.org/10.1590/ S0100-67622003000600004.

Nakazono EM, Costa MC, Futatsug K, Paulilo MTS. Crescimento inicial de Euterpe edulis Mart. em diferentes regimes de luz. Revista Brasileira de Botanica. Brazilian Journal of Botany 2001; 24(2): 173-179.

Nomura ES, Lima JD, Rodrigues DS, Garcia VA, Fuzitani EJ. Influência do substrato e do tipo de fertilizante na aclimatação de mudas de bananeira 'prata-anã'. Ciência e Agrotecnologia 2009; 33(3): 773-779. http://dx.doi. org/10.1590/S1413-70542009000300016.

Poorter $\mathrm{H}$, Nagel O. The role of biomass allocation in the growth response of plants to different levels of light, $\mathrm{CO}^{2}$, nutrients and water: a quantitative review. Australian Journal of Plant Physiology 2000; 27(3): 595-607.

Reis SM, Marimon BH Jr, Morandi OS, Santos CO, Oliveira B, Marimon BS. Desenvolvimento inicial e qualidade de mudas de copaifera langsdorffii desf. sob diferentes níveis de sombreamento. Ciência Florestal 2016; 26(1): 11-20. http://dx.doi.org/10.5902/1980509821061.
Rossa UB, Angelo AC, Nogueira AC, Reissmann CB, Grossi F, Ramos MR. Fertilizante de liberação lenta no crescimento de mudas de araucaria angustifolia e ocotea odorífera. Floresta 2011; 41(3): 491-500. http://dx.doi. org/10.5380/rf.v41i3.24040.

Rossa ÜB, Angelo AC, Nogueira AC, Westphalen DJ, Bassaco MVM, Milani JEF et al. Fertilizante de liberação lenta no desenvolvimento de mudas de schinus terebinthifolius e sebastiania commersoniana. Floresta 2013; 43(1): 93-104. http://dx.doi.org/10.5380/rf.v43i1.25690.

Rossa ÜB, Angelo AC, Westphalen DJ, Oliveira FEM, Silva FF, Araujo JC. Fertilizante de liberação lenta no desenvolvimento de mudas de anadenanthera peregrina (l.) speg. (angico-vermelho) e schinus terebinthifolius raddi (aroeira-vermelha). Ciência Florestal 2015; 25(4): 841-852. http://dx.doi.org/10.5902/1980509820582.

Rossa UB, Angelo AC, Westphalen DJ, Utima AY, Milani JEF, Monzani RM. Fertilizante de liberação lenta na produção de mudas de gallesia integrifolia (spreng.) harms. Revista Agrocientífica 2014; 1(1): 23-32.

Santelices R, Espinoza S, Cabrera AM. Effects of shading and slow release fertilizer on early growth of Nothofagus leonii seedlings from its northernmost distribution in Central Chile. Bosque 2015; 36(2): 179-185. http://dx.doi. org/10.4067/S0717-92002015000200004.

Serrano LAL, Cattaneo LF, Ferreguetti GA. Adubo de liberação lenta na produção de mudas de mamoeiro. Revista Brasileira de Fruticultura 2010; 32(3): 874-883. http://dx.doi.org/10.1590/S0100-29452010005000084.

Silva BMS, Lima JD, Dantas VAV, Moraes WS, Sabonaro DZ. Efeito da luz no crescimento de mudas de hymenaea parvifolia huber. Revista Árvore 2007; 31(6): 1019-1026. http://dx.doi.org/10.1590/S0100-67622007000600006.

Silva RBG, Simões D, Andrade FR, Silva MR. Qualidade de mudas seminais de eucalipto em função dos substratos e fertilização de liberação controlada. Interciencia 2013; 38(3): 215-220.

Viégas IJM, Meireles RO, Frazão DAC, Conceicão HEO. Avaliação da fertilidade de Latossolo amarelo de textura media para o cultivo de açaizeiro no estado Pará. Revista de Ciências Agrárias 2009; 52(10): 23-36.

Yokomizo GK-I, Mochiutti S, Queiroz JAL, Santos GR, Furtado RG, Brandão AP et al. Estimativas de parâmetros genéticos para caracteres de frutos em açaizeiros no Amapá. Ciência Florestal 2016; 26(3): 985-993. http:// dx.doi.org/10.5902/1980509824227.

Zamunér AN Fo, Venturin N, Pereira AV, Pereira EBC, Macedo RLG. Doses of controlled-release fertilizer efor production of rubber tree roottocks. Cerne 2012; 18(2): 239345. http://dx.doi.org/10.1590/S0104-77602012000200008.

Zancheta AA, Mazzini RB, Batista GS, Melo RF, Pivetta KFL. Growth of Euterpe oleraceae seedlings under diferente color nets and light conditions. Acta Horticulturae 2013;(1000): 293-300. http://dx.doi.org/10.17660/ ActaHortic.2013.1000.39. 